\title{
Estimating grazing index values for plants from arid regions
}

\author{
PIÉRRE C. V. DU TOIT
}

Author is principal agricultural scientist, Pasture Science Department, Grootfontein Agricultural Development Institute, Private Bag X529, 5900, Middleburg, Republic of South Africa.

\begin{abstract}
The Ecological Index Method impacted directly on the estimation of grazing capacities in the Karoo, an arid region in South Africa. Due to inherent deficiencies in the ecological index method, index values formed a disjunct series, 10, 7, 4, and 1 and the fact that different value systems were employed to score plant species, necessitated that index values of species commonly encountered during botanical surveys be subjectively adjusted by means of a species by species comparison, forming a continuous series of index values. These index values were still subjective value judgements of the agronomic value of the Karoo plant species. The author felt that a method should be developed to objectively estimate grazing index values from certain plant variables, i.e. size, animal available dry matter production, and chemical properties of the species. The use of these properties would describe the agronomic value of the plant species, which would lead to agronomically sound current grazing capacities being estimated. The following 2 models were proposed to deal with the karoo subshrubs and the grasses of the karoo separately. Grazing index value for the karoo subshrubs $=\{$ (canopy spread cover + available forage $+\mathbf{T D N}+[\mathrm{K} \div(\mathrm{Ca}+\mathrm{Mg})]) \div$ ether extract $\} \div 100$, and grazing index value for the grasses $=$ $\{$ canopy spread cover + available forage + TDN $+[\mathrm{K} \div(\mathrm{Ca}+$ Mg)] $x$ ether extract $\} \div 100$.
\end{abstract}

Key Words: available dry matter production, canopy spread cover, current grazing capacity, $K \div(\mathrm{Ca}+\mathrm{Mg})$ ratio, total digestible nutrients

Publication of the Ecological Index Method by Vorster (1982) directly influenced the estimation of grazing capacities in the Karoo. He allocated index values to the karoo plants on the basis:

1) perennial climax grasses, index value 10; in close agreement with Tainton et al. (1980);

2) perennial sub-climax grasses and palatable karoo subshrubs, index value 7

3) perennial pioneer grasses and the less palatable karoo subshrubs, index value 4; and

4) annual pioneer grasses, unpalatable karoo subshrubs and invader plants, index value 1 .

This method has been used throughout the Karoo, with largely acceptable results. The ecological index values are used in the computation of range condition scores (see Tainton 1981), following surveys of sample sites. Grazing capacities for these sample sites are then estimated from the range condition scores. Since

Manuscript accepted 25 Nov. 1999.

\section{Resumen}

El método de Indice Ecológico impactó directamente en la estimación de la capacidad de apacentamiento del Karoo, una región árida de Sudáfrica. Debido a las deficiencias inherentes del método de Indice Ecológico los valores de los indices formaron un serie disyuntiva, 10, 7, 4 y 1, y el hecho de que se emplearon diferentes sistemas de valores para calificar las plantas, exige que los valores de los indices para las especies comúnmente encontradas durante los reconocimientos botánicos sean subjetivamente ajustados mediante la comparación de especies por especie formando series continuas de valores de los indices. Estos valores de los indices todavía son valores subjetivos del valor agronómicos de las especies de plantas del Karoo. El autor sintió que se debería desarrollar un método para estimar objetivamente los valores del indice de apacentamiento a partir de ciertas variables de la planta, por ejemplo, el tamaño, la disponibilidad de materia seca para el animal y las propiedades químicas de las especies. El uso de estas propiedades describirá el valor agronómico de las especies vegetales, el cual conduciría a la estimación sensata de la capacidad de apacentamiento. Los siguientes 2 modelos fueron propuestos para tratar por separado los arbustos y zacates del Karoo. El valor del indice de apacentamiento para arbustos fue igual a: $\{$ (cobertura de la copa extendida + forraje disponible + NTD + $[\mathrm{K} \div(\mathrm{Ca}+\mathrm{Mg})]) \div$ extracto etéreo $\} \div 100$ y el valor del indice de apacentamiento para zacates fue igual a: \{cobertura de la copa extendida + forraje disponible + NTD + $[\mathrm{K} \div(\mathrm{Ca}+\mathrm{Mg})])$ x extracto etéreo $\} \div 100$.

Vorster (1982) scored the grasses on ecological attributes and karoo subshrubs on palatability, an agronomic attribute, the range condition score computed for the sample site represents the ecological state of health of the grass sward on one hand, but the agronomic state of health of the karoo subshrubs on the other (see Tainton 1981). Since the score is based partly on ecological principles and partly on palatability, it is inappropriate to estimate grazing capacities, which are agronomic values, from these range condition scores which are assumed to indicate the agronomic potential of the site to support livestock. Several other factors, for instance dry matter production (Botha et al. 1993) need to be considered when a realistic grazing capacity is to be estimated.

The ecological index method is largely dependent upon classical succession theory, similar to many methods currently employed elsewhere in South Africa (Foran et al. 1978, Tainton et al. 1980, Mentis et al. 1980, Hardy and Hurt 1989, Hurt and Bosch 1991). Another of the deficiencies was that some of the late developmental stage grasses, previously referred to as climax grasses, received too high an index value to be used in the computations when estimating the current grazing capacity (Tainton 
et al. 1980, Edwards 1981, Vorster 1982). Research revealed that not all the late developmental stage grasses should have an index value of 10 (Du Toit and Botha 1993). Because of the above mentioned deficiencies, a committee investigated the apparent shortcomings in order to correct them in an effort to move away from the classical succession theory. The index values of all the species commonly encountered during botanical surveys, were adjusted subjectively by means of a species by species comparison. Each species being assessed on the basis of the following 6 variables:

1) The ability to produce forage, i.e. the amount of grazable dry matter produced per year: Low producers score 1 , high producers score 10.

2) The nutritional value during the growing season: Species with a low nutritional value score 1 , species with a high nutritional value score 10 .

3) The nutritional value during the dormant season, as in No. 2.

4) Relative ease with which the species can be grazed i.e. presence or absence of spines: spiny species score 1 , species without spines score 10 . The presence of resins and aromatic oils downgraded the score due to anti-herbivory.

5) Perenniality: Annual species score 1, strong perennial sodforming grasses score 10.

6) Ability of the plant to protect the soil against surface soil erosion: Upright karoo subshrubs have a low score, decumbent bushes score fairly high, annual tufted grasses score 1 , tufted perennial grasses, depending on productivity and habit, have an intermediate score due to the erosive channeling effect they may have on runoff water, sod forming grasses, where infiltration of rainwater is heightened, score 10.

These 6 agronomic properties of the species were chosen to ensure that individual species scores were comparable and the estimate free from bias. Each variable scored a maximum of 10 . Individual variable scores were summed and the final species score calculated to occupy a position between 0 and 10 . The average of the scores submitted by the members, and standard deviation was calculated for each species score. Values falling outside the range $\mathrm{x} \pm \mathrm{SD}$ were discarded. A new mean was calculated for the remaining values. The resultant score called the subjective grazing index value was vetted taking into account scores of related species, as well as unrelated species of known similar grazing value. The phases of the operational research study (Wilkes 1989) were followed.

These index values, however, still represent subjective value judgements of the actual agronomic value of the Karoo plant species. The author felt that a method should be developed to estimate grazing index values more objectively from certain agronomic plant variables; size, dry matter production, and chemical properties of the species. These properties were studied for a period of 3 years, to largely exclude extreme variations in productivity which is so characteristic of vegetation from semiarid range types (Sneva and Hyder 1962). Species from distinct agro-ecological regions were studied. It was attempted to study related species in the different regions, to ascertain differences in grazing value between different species in an area and between related species of different areas. These objective grazing index values will replace the ecological index values. To avoid future confusion as to which index values have been used, and that an agronomic method of grazing capacity estimation was used, the ecological index method is replaced by the Grazing Index Method (Du Toit 1995).

Grazing index values estimated by the model, should reflect agronomic values of plant species more objectively and when used in conjunction with the Grazing Index Method, estimate more acceptable current grazing capacities. These grazing index values should furthermore verify the relative position of the species in the series, when compared to the subjective grazing index values developed earlier (Du Toit et al. 1995).

\section{Methodology}

\section{Canopy spread cover}

The canopy spread cover of a number of grasses and bushes was measured at random at each locality from 1990 to 1993 . Fifty plants per species were selected from small to large plants, including the range of sizes normally found within the species. A frame $1 \mathrm{~m} \times 1 \mathrm{~m}$, subdivided into blocks of $50 \mathrm{~mm} \times 50 \mathrm{~mm}$ for the large species and $25 \mathrm{~mm} \times 25 \mathrm{~mm}$ for the smaller species, was used for this purpose. The canopy spread cover was estimated by counting the blocks of which half or more of each block was engaged by the perpendicular projection of the crown (Goebel et al. 1958). The number of blocks counted were then expressed as square centimeters of canopy spread cover. The canopy spread cover of 50 plants per species obtained this way included a representative sample of sizes, from small plants to large plants. The 50 measurements gave a reliable average value (Roux 1963). The plants were harvested in toto at a height of approximately $20 \mathrm{~mm}$ to $50 \mathrm{~mm}$ above the soil surface. The plants were selected at random over an area of 1 hectare (Vlok 1963), to minimize variations in plant ecotypic differences. The harvested material was separated into potentially grazable and ungrazable material on the basis of the $2 \mathrm{~mm}$ rule of thumb (Botha 1981, Du Toit 1996a). The $2 \mathrm{~mm}$ rule of thumb states that stems thicker than $2 \mathrm{~mm}$ are not grazed. While stems thicker than $2 \mathrm{~mm}$ were regarded as ungrazable, thinner stems contributed to the available grazable forage (Botha 1981, Du Toit 1993). Grass tufts were harvested by clipping to a stubble height of $20-50 \mathrm{~mm}$ and the whole fraction was regarded as being grazable. Plant material was dried in a forced draft oven between $60^{\circ} \mathrm{C}$ to $80^{\circ} \mathrm{C}$, for 24 hours.

\section{Relation between canopy spread cover and mass}

The canopy spread cover : total mass relation of specific species were determined by regression to determine the relation between plant cover and the available forage (Payne 1974).

\section{Chemical analyses}

The grazable material was chemically analyzed for $\mathrm{N}$ according to the Kjeldahl method (AOAC 1964), Ca, P, Na, Mg, K were analyzed by atomic adsorption spectrophotometer, (Homer and Parker 1961) and acid detergent fibre was analyzed according to a modified Weende method (Van Soest 1963).

\section{Model development}

The proposed model attempts to objectively allocate a grazing index value to each of the studied species, based on the agronomic variables; size of the species i.e. canopy spread cover, the cornerstone of the range condition assessment technique, animal available dry matter, and certain chemical properties. Stepwise regressions (Statistical Graphics Corporation 1991) of the subjective grazing index values on the values obtained for the different parameters of the studied species indicated the most important elements to be included in the model. 
Taxonomy

Nomenclature follows Arnold and De Wet (1993). Species names used in this paper and in the tables with their authorities are given in Table 1.

\section{Results and discussion}

\section{Available forage and canopy spread cover}

The relation between available forage and canopy spread cover, for all values, has a coefficient of determination, $\mathrm{r}^{2}=$ 0.62 . The slope of the regression line is less than $45^{\circ}$. This means that as the plants increase in size, there is not the expected corresponding increase in available forage. With the available forage being over-estimated by about 25\% (Du Toit 1993, 1996a), the regression relation should have a slope of much less than $45^{\circ}$. The available mass recovered from a plant with a certain canopy spread cover varies considerably. Therefore, cover on its own does not provide a reliable estimate of available forage, in contrast to the finding of Mueller Dombois and Ellenberg (1974). Uresk (1990) proposed that frequency and canopy spread cover be multiplied to render an index of forage mass, which would probably be a reliable indication of available forage. In this case the relation between plant cover, available forage and forage value was to be used to calculate a grazing index value for each species. Floristic composition measured by the grazing index method, together with the grazing index values of the species would then describe the grazing capacity.

\section{Nutrient requirements of grazing ani- mals}

According to Du Toit et al. (1940), growing sheep needs approximately $0.16 \%$ calcium and $0.14 \%$ phosphorus in their diet, while Louw (1969) recommends that the diet must contain between $0.2 \%$ to $0.5 \%$ calcium and $0.2 \%$ to $0.46 \%$ phosphorus, which agrees with values quoted by Woods (1959). The calcium : phosphorus ratio must be in the region of 1.0 for normal growth and development.

Potassium, calcium, and magnesium are included as the $\mathrm{K} \div(\mathrm{Ca}+\mathrm{Mg})$ ratio. These elements have a direct influence on the grazing value since unfavourable ratios lead to tetany (Kemp and T'Hart 1957, Kidambi et al. 1989). Values of these macronutrients are included in the formulae for the objective estimation of the grazing index values. Low or high values and unfavourable ratios have detrimental
Table 1. Species names and their authorities used in this paper and in Tables 1 to 3.

Chrysocoma ciliata $\mathrm{L}$.

Eberlanzia ferox (L. Bol.) L. Bol.

Eriocephalus aspalathoides DC.

Eriocephalus ericoides (L.f.) Druce

Eriocephalus spinescens Burch.

Felicia fascicularis DC.

Felicia filifolia (Vent.) Burtt Davy

Felicia macrorrhiza (Thunb.) DC.

Felicia muricata (Thunb.) Nees

Galenia procumbens L.f.

Galenia secunda (L.f.) Sond.

Helichrysum dregeanum Sond. \& Harv.

Helichrysum lucilioides Less.

Hermannia desertorum Eckl. \& Zeyh.

Hertia pallens (DC.) Kuntze

Lycium cinerium Thunb. (Sens. Lat.)

Monechma incanum (Nees) C.B.Cl.

Nenax microphylla (Sond.) Salter

Osteospermum microphyllum DC.

Osteospermum spinescens Thunb.

Pentzia globosa Less.

Pentzia incana (Thunb.) Kuntze

Pentzia spinescens Less.

Phymaspermum parvifolium (DC.) Benth. \&

Hook. ex Jackson

Plinthus cryptocarpus Fenzl

Plinthus karooicus Verdoorn

Protasparagus suaveolens (Burch.) Oberm.

Pteronia adenocarpa Harv.

Pteronia glauca Thunb.

Pteronia glomerata L.f.

Pteronia sordida N.E.Br.

Pteronia staehelinoides DC.

Pterothrix spinescens DC.

Rhigozum obovatum Burch.

Rosenia humilis (Less.) Bremer

Rosenia oppositifolia (DC.) Bremer

Salsola calluna Fenzl ex C.H.Wr.

Salsola rabieana Verdoorn

Salsola tuberculata (Moq.) Fenzl

Walafrida geniculata (L.f.) Rolfe

Walafrida saxatilis (E.Mey.) Rolfe

Zygophyllum gilfillanii N.E.Br.

Zygophyllum lichtensteinianum Cham. \&

Schlechtd.

Zygophyllum microphyllum L.f.

Grasses

Aristida adscensionis L.

Aristida congesta Roem. \& Schult. subsp. congesta

Aristida diffusa Trin. subsp. diffusa

Cymbopogon plurinodis (Stapf) Stapf ex Burtt Davy

Cynodon dactylon (L.) Pers.

Digitaria eriantha Steud.

Enneapogon desvauxii Beauv.

Eragrostis bergiana (Kunth) Trin.

Eragrostis chloromelas Steud.

Eragrostis curvula (Schrad.) Nees var. conferta

Eragrostis lehmanniana Nees var. lehmanniana

Eragrostis obtusa Munro ex Fical. \& Hiern

Fingerhuthia africana Lehm.

Heteropogon contortus (L.) Roem. \& Schult.

Hyparrhenia hirta (L.) Stapf

Merxmuellera disticha (Nees) Conert

Sporobolus fimbriatus (Trin.) Nees

Stipagrostis ciliata (Desf.) De Winter var. capensis

Stipagrostis obtusa (Del.) Nees

Themeda triandra Forssk. 
Table 2. Objective grazing index values (OGIV) calculated for species from the False Upper Karoo (Acocks 1988), compared to their corresponding subjective grazing index values (SGIV), illustrating the annual and seasonal variation.

\begin{tabular}{|c|c|c|c|c|c|c|}
\hline \multirow[b]{2}{*}{ 1990/91 } & \multicolumn{5}{|c|}{ OGIV } & \multirow[t]{2}{*}{ SGIV } \\
\hline & May & Aug. & Nov. & Jan. & Mean & \\
\hline Chrysocoma ciliata & 1.22 & 0.31 & 1.29 & 0.51 & 0.83 & 1.50 \\
\hline Aristida congesta & 3.36 & 1.92 & 0.94 & 1.07 & 1.82 & 1.30 \\
\hline Digitaria eriantha & 19.59 & 7.72 & 13.51 & 6.46 & 11.82 & 8.90 \\
\hline Themeda triandra & 15.04 & 10.19 & 8.31 & 6.69 & 10.06 & 9.30 \\
\hline Eriocephalus spinescens & 3.09 & 2.75 & 0.29 & 2.73 & 2.22 & 4.50 \\
\hline Pentzia incana & 1.67 & 1.17 & 1.42 & 1.93 & 1.55 & 5.70 \\
\hline Rosenia humilis & 3.28 & 2.90 & 3.99 & 3.03 & 3.30 & 3.50 \\
\hline Heteropogon contortus & 4.17 & 5.36 & 4.37 & 3.77 & 4.42 & 7.20 \\
\hline Stipagrostis ciliata & 3.78 & 4.48 & 2.38 & 3.61 & 3.56 & 7.20 \\
\hline Stipagrostis obtusa & 3.49 & 4.46 & 1.01 & 2.34 & 2.83 & 6.60 \\
\hline Aristida congesta & 1.82 & 1.58 & 0.78 & 0.85 & 1.26 & 1.30 \\
\hline Heteropogon contortus & 3.77 & 5.06 & 4.15 & 3.98 & 4.24 & 7.20 \\
\hline Themeda triandra & 6.64 & 6.26 & 5.65 & 4.70 & 5.81 & 9.30 \\
\hline
\end{tabular}

effects on animal production (Van Hoven and Ebedes 1988). Low values lead to serious deficiencies in animal feeding (Woods 1959). Unfavourable values negatively affect index values.

In addition to the chemical properties mentioned above, the $\%$ ash and ether extract of the species were obtained from the literature for analyses previously carried out on plantspecies occurring in the same areas (Louw et al. 1968a, 1968b, 1968c, Steenkamp and Hayward 1979, Botha and Nash 1990, Botha et al. 1990a, 1990b, 1990c).

\section{Total digestible nutrients (TDN)}

Because of the prominence that total digestible nutrients receives in animal feeding ration formulations (Maynard and Loosli 1962), in the comparison of different feedstuffs (Swift 1957) and in this study, the comparison of different natural forages, it is included in these equations as a primary variable. The 2 variables incorporated in the determination of TDN (Glover et al. 1960, Bartholomew 1985, Bredon and Meaker undated), i.e. the percentages of nitrogen and acid detergent fibre, can be excluded from the model, since their influence on the index value is already taken into account.

The formula for the estimation of TDN using acid detergent fibre, is composed of the formulae developed by:

1) Glover et al. (1960) and Bredon and Meaker (undated) where : TDN =
$75.1+[(6.25 \times \log \%$ crude protein $)-$ $0.75 \times \%$ crude fibre)] and;

2) $\mathrm{Du}$ Toit (1996b) where : Crude fibre $=$ $-4.32+0.92 \times \%$ acid detergent fibre.

$\therefore \mathrm{TDN}=75.1+\{(6.25 \times \log \% \mathrm{~N})-$ $(0.75 \times[-4.32+(0.92 \times \%$ acid detergent fibre)])\} (Du Toit 1996b).

\section{Proposed model, used to estimate} grazing index values

The model takes into account the size of the plant i.e. canopy spread cover, which is the cornerstone of the method of botanical survey for estimating grazing capacity, through the Grazing Index Method. Two approaches were followed with the formulation of the model. In the case of the karoo subshrubs the ether extract value negatively affects the grazing value, on account of it's contribution to the smell and taste of the karoo subshrubs. The higher the ether extract value of the karoo subshrub, the higher the resin and aromatic oil content. Experience teaches that plants with high resin and aromatic oil contents are the more unpalatable karoo subshrubs. Compare the unpalatable karoo subshrub Chrysocoma ciliata with ether extract values of 8.9 in summer and 9.2 in winter to the more palatable karoo subshrub Pentzia incana with ether extract values of 2.3 and 3.9 in summer and winter respectively (Botha et al. 1990c) (Table $2)$. High ether extract contents act as deterrents to herbivores, while the higher the ether extract values of certain shrubs, the higher the loss of energy rich esters, ethers and aldehydes through the urine of sheep (Cook et al. 1952). The usable energy of these forages is not as high as their calculated TDN values indicate. Consequently the sum of the calculated values of the different variables is divided by the ether extract value, a lower index value for karoo subshrubs with high ether extract values are estimated, in accordance with their relatively low nutritional value.

\section{Model a, grazing index value for karoo subshrubs}

Grazing index value for the karoo subshrubs $=\{$ (canopy spread cover + avail able forage $+\mathrm{TDN}+[\mathrm{K} \div(\mathrm{Ca}+\mathrm{Mg})]) \div$ ether extract $\} \div 100$ (Du Toit 1996b) (Table 3).

In the case of grasses, ether extract values positively contributes to the grazing value, through the carotene content (Van Der Merwe 1985). Grasses with high ether extract values are late developmental stage species, they are more productive and assumed to be more nutritious, than early developmental stage grasses with normally low ether extract percentages and low carotene contents. High ether extract values indicate high carotene contents of the grasses and a more favourable vitamin A, B, E, and probably D content (McDonald et al. 1973). Late developmental stage grasses Digitaria eriantha and Themeda triandra have the highest ether extract values, 2.02 
Table 3. Mean objective grazing index values (OGIV) calculated according to the model, compared to the subjective grazing index values (SGIV)

\begin{tabular}{|c|c|c|c|c|c|}
\hline \multirow[t]{2}{*}{ Karoobushes } & \multirow[b]{2}{*}{ Min } & \multicolumn{2}{|c|}{ OGIV } & \multirow[b]{2}{*}{ Std dev } & \multirow[t]{2}{*}{ SGIV } \\
\hline & & Max & Mean & & \\
\hline Chrysocoma ciliata & 0.31 & 1.29 & 0.83 & 0.43 & 1.50 \\
\hline Eberlanzia ferox & 1.07 & 3.68 & 1.96 & 0.67 & 2.70 \\
\hline Eriocephalus ericoides & 0.57 & 7.67 & 2.54 & 1.67 & 5.00 \\
\hline Eriocephalus spinescens & 0.29 & 5.77 & 3.65 & 1.20 & 4.50 \\
\hline Felicia fascicularis & 0.22 & 0.95 & 0.48 & 0.23 & 6.20 \\
\hline Felicia filifolia & 1.94 & 4.23 & 2.63 & 0.93 & 5.90 \\
\hline Felicia macrorrhiza & 1.70 & 2.37 & 2.05 & 0.24 & 5.70 \\
\hline Galenia secunda & 2.53 & 6.21 & 4.92 & 1.46 & 4.70 \\
\hline Helichrysum dregeanum & 0.43 & 0.53 & 0.47 & 0.04 & 6.30 \\
\hline Helichrysum lucilioides & 0.94 & 3.09 & 1.75 & 0.57 & 5.20 \\
\hline Hermannia desertorum & 1.09 & 1.35 & 1.21 & 0.09 & 5.90 \\
\hline Monechma incanum & 6.01 & 18.69 & 9.76 & 5.20 & 5.40 \\
\hline Nenax microphylla & 0.50 & 4.07 & 1.16 & 0.83 & 7.00 \\
\hline Osteospermum microphyllum & 1.51 & 1.79 & 1.66 & 0.10 & 7.00 \\
\hline Osteospermum spinescens & 2.92 & 6.03 & 4.63 & 1.34 & 6.00 \\
\hline Pentzia globosa & 0.71 & 1.73 & 1.26 & 0.30 & 4.80 \\
\hline Pentzia incana & 0.97 & 2.01 & 1.50 & 0.33 & 5.70 \\
\hline Pentzia spinescens & 0.44 & 6.16 & 2.43 & 1.12 & 4.80 \\
\hline Phymaspermum parvifolium & 0.39 & 3.71 & 1.60 & 1.12 & 6.20 \\
\hline Plinthus cryptocarpus & 0.54 & 4.70 & 1.95 & 1.35 & 6.70 \\
\hline Plinthus karooicus & 0.81 & 3.06 & 2.06 & 0.72 & 6.40 \\
\hline Pteronia adenocarpa & 1.19 & 3.19 & 1.82 & 0.59 & 3.90 \\
\hline Pteronia glauca & 1.89 & 3.81 & 2.77 & 0.80 & 3.20 \\
\hline Pteronia glomerata & 1.15 & 2.63 & 2.06 & 0.55 & 3.90 \\
\hline Pteronia staehelinoides & 0.14 & 0.22 & 0.18 & 0.03 & 4.00 \\
\hline Pterothrix spinescens & 0.11 & 3.03 & 1.91 & 1.91 & 2.00 \\
\hline Rosenia humilis & 2.44 & 6.06 & 4.00 & 0.89 & 3.50 \\
\hline Rosenia oppositifolia & 0.50 & 1.24 & 0.82 & 0.30 & 3.10 \\
\hline Salsola calluna & 4.24 & 5.71 & 5.11 & 0.62 & 7.20 \\
\hline Salsola rabieana & 2.79 & 4.09 & 3.39 & 0.42 & 6.70 \\
\hline Salsola tuberculata & 1.64 & 6.88 & 4.21 & 2.04 & 6.90 \\
\hline Walafrida geniculata & 2.01 & 4.29 & 3.33 & 0.75 & 7.00 \\
\hline Walafrida saxatilis & 0.54 & 0.86 & 0.69 & 0.12 & 2.00 \\
\hline Zygophyllum lichtensteinianum & 1.20 & 1.62 & 1.43 & 0.17 & 4.00 \\
\hline Zygophyllum microphyllum & 2.91 & 4.52 & 3.79 & 0.57 & 4.00 \\
\hline \multicolumn{6}{|l|}{ Grasses } \\
\hline$\overline{\text { Aristida congesta }}$ & 0.78 & 3.36 & 1.54 & 0.80 & 1.30 \\
\hline Aristida diffusa & 2.56 & 11.00 & 5.75 & 2.36 & 5.10 \\
\hline Digitaria eriantha & 4.82 & 19.59 & 8.58 & 4.47 & 8.90 \\
\hline Eragrostis curvula conferta & 0.95 & 4.98 & 2.76 & 1.40 & 6.90 \\
\hline Eragrostis lehmanniana & 1.87 & 5.64 & 2.70 & 0.89 & 5.40 \\
\hline Fingerhuthia africana & 2.07 & 5.19 & 3.41 & 1.11 & 6.60 \\
\hline Heteropogon contortus & 3.77 & 5.36 & 4.33 & 0.55 & 7.20 \\
\hline Hyparrhenia hirta & 7.74 & 10.78 & 8.71 & 1.21 & 6.30 \\
\hline Merxmuellera disticha & 4.91 & 12.24 & 7.46 & 2.82 & 5.00 \\
\hline Sporobolus fimbriatus & 5.22 & 10.02 & 7.08 & 1.80 & 9.50 \\
\hline Stipagrostis ciliata & 1.87 & 12.93 & 5.82 & 3.12 & 7.20 \\
\hline Stipagrostis obtusa & 0.62 & 5.65 & 2.41 & 1.28 & 6.60 \\
\hline Themeda triandra & 2.32 & 15.04 & 6.10 & 3.09 & 9.30 \\
\hline
\end{tabular}

(summer) and 1.92 (winter) as opposed to the early developmental stage grasses Aristida congesta and A. adscensionis with a content of 1.34 in both summer and winter (Botha et al. 1990c) (Table 2) (Acocks 1988). Therefore the sum of the calculated values of the different variables is multiplied by the ether extract value. This action favours grasses with high ether extract values. ing from the use of the objectively estimated grazing index values are closer to the accepted grazing capacity norms than where the subjectively estimated grazing index values have been used. Assuming that the grazing capacity norms set for the various areas are correct, the conclusion can be reached that it is more appropriate to use the objectively estimated grazing index values in the estimate of the grazing capacity, than either the ecological index values or the subjectively estimated grazing index values. It follows that the use of the objectively estimated grazing index values will result in more realistic estimates of the current grazing capacities of rangeland. Furthermore, the objectively estimated grazing index values verify the relative position of the subjectively estimated grazing index values of the different plant species on the grazing index value scale.

With this model, the grazing index value of any species can be estimated with a certain degree of confidence. Quality parameters can be gleaned from the literature, or be determined empirically. It may be possible to refine this model, by incorporating some of the parameters excluded at the moment. However, different grazing index values are estimated for species for the different seasons (Table 2) which in turn sheds more light on the concept of palatable and unpalatable species, as well as the seasonal palatability of a species.

\section{The index value scale}

It is questionable whether the top of the grazing index value scale should be 10 . The use of a scale with values from 1 to 10 has become customary and is often proposed in biological work (cf. Curtis and McIntosh 1951, Brown and Curtis 1952, Vorster 1982, Hurt and Bosch 1991). It is clear that unbeknown to the estimators of the subjectively estimated grazing index values, the old ecological index method scale (Vorster 1982) and the climax adaptation values (Curtis and McIntosh 1951, Brown and Curtis 1952) played an important role in positioning the subjective estimates of the grazing index values. From the foregoing it then becomes clear that all the subjectively estimated grazing index values will have to be adjusted, mainly downwards, so as to fall into line with the objectively estimated grazing index values. Once this action is accomplished, current grazing capacities can be estimated much more reliably and realistically and different homogeneous areas can be directly compared to each other on a realistic and agriculturally sound scientific basis. 
Table 4. Botanical composition, percentage canopy spread cover (CS), range condition scores (VCS) and the respective estimated current grazing capacities (CGC) presented for 7 sample sites from 4 reasonably homogeneous areas in the Karoo, i.e. the Bushmanland, the Eastern Mixed Karoo, the Great Karoo and the Central Upper Karoo. Sites follow a gradient from the arid northwest through the south and central Karoo to the relatively moist north eastern Karoo. The ecological, subjective grazing index and objective grazing index values of the different species are compared, as well as the results of their respective products with the percentage strikes on the species. Where no OGIV was available for a plant species, the SGIV was included as the OGIV score, this is indicated by an asterisk next to the species name. CGC is given in ha.LSU ${ }^{-1}$. EIV $=$ ecological index value, SGIV = subjective grazing index value and OGIV = objective grazing index value.

Grappies Farm (29 $\left.25^{\prime} \mathrm{S}, 19^{\circ} 57^{\prime} \mathrm{E}\right)$, Pofadder district; June 1992, median rainfall $82 \mathrm{~mm} . \mathrm{a}^{-1}$, grazing capacity norm 39 ha.LSU ${ }^{-1}$, Bushmanland.

\begin{tabular}{|c|c|c|c|c|c|c|c|}
\hline & $\%$ & EIV & Score & SGIV & Score & OGIV & Score \\
\hline Aristida congesta & 1 & 1 & 1 & 1.3 & 1.3 & 1.5 & 1.5 \\
\hline Eriocephalus spinescens & 2 & 4 & 8 & 4.5 & 9.0 & 3.7 & 7.4 \\
\hline Stipagrostis ciliata & 39 & 10 & 390 & 7.2 & 280.8 & 5.8 & 226.2 \\
\hline $\mathrm{CS}$ & 67 & VCS & 649 & VCS & 456 & VCS & 295.1 \\
\hline$\overline{\mathrm{CGC}}$ & & & 7.2 & & 10.2 & & 15.7 \\
\hline
\end{tabular}

Knolepark Farm (30 $\left.38^{\prime} \mathrm{S}, 26^{\circ} 20^{\prime} \mathrm{E}\right)$, Burgersdorp district; February 1992, median rainfall $450 \mathrm{~mm} . \mathrm{a}^{-1}$, grazing capacity norm 10 ha.LSU ${ }^{-1}$, Eastern Mixed Karoo.

\begin{tabular}{|c|c|c|c|c|c|c|c|}
\hline & $\%$ & EIV & Score & SGIV & Score & OGIV & Score \\
\hline Cymbopogon plurinodis* & 78 & 10 & 780 & 7.6 & 592.8 & 7.6 & 592.8 \\
\hline Digitaria eriantha & 2 & 10 & 20 & 8.9 & 17.8 & 8.3 & 16.6 \\
\hline Pentzia globosa & 1 & 4 & 4 & 4.8 & 4.8 & 1.3 & 1.3 \\
\hline Themeda triandra & 9 & 10 & 90 & 9.3 & 83.7 & 6.1 & 54.9 \\
\hline$\overline{\mathrm{CS}}$ & 90 & VCS & 894 & VCS & 699 & VCS & 665.6 \\
\hline CGC & & & 5.2 & & 6.6 & & 7.0 \\
\hline
\end{tabular}

Diephoek Farm (3007'S, $\left.24^{\circ} 15^{\prime} \mathrm{E}\right)$, Petrusville district; July 1992, median rainfall $312 \mathrm{~mm} \cdot \mathrm{a}^{-1}$, grazing capacity norm 20 ha.LSU ${ }^{-1}$, Eastern Mixed Karoo.

\begin{tabular}{|c|c|c|c|c|c|c|c|}
\hline & $\%$ & EIV & Score & SGIV & Score & OGIV & Score \\
\hline Eragrostis lehmanniana & 30 & 7 & 210 & 5.4 & 162.0 & 2.7 & 81.0 \\
\hline Pentzia globosa & 15 & 4 & 60 & 4.8 & 72.0 & 1.3 & 19.5 \\
\hline Aristida congesta & 4 & 1 & 4 & 1.3 & 5.2 & 1.5 & 6.0 \\
\hline Enneapogon desvauxii* & 1 & 1 & 1 & 1.0 & 1.0 & 1.0 & 1.0 \\
\hline Hertia pallens* & 2 & 1 & 2 & 1.2 & 2.4 & 1.2 & 2.4 \\
\hline Lycium cinereum* & 1 & 1 & 1 & 3.0 & 3.0 & 3.0 & 3.0 \\
\hline Protasparagus suaveolens* & 4 & 1 & 4 & 1.0 & 4.0 & 1.0 & 4.0 \\
\hline Eragrostis bergiana* & 3 & 4 & 12 & 2.8 & 8.4 & 2.8 & 8.4 \\
\hline $\mathrm{CS}$ & 74 & VCS & 374 & VCS & 3.35 & VCS & 167.7 \\
\hline$\overline{\mathrm{CGC}}$ & & & 12.4 & & 13.9 & & 27.7 \\
\hline
\end{tabular}

Hillstone Farm (31 $\left.20^{\prime} \mathrm{S}, 25^{\circ} 31^{\prime} \mathrm{E}\right)$, Middelburg district; July 1992, median rainfall 346 mm.a ${ }^{-1}$, grazing capacity norm 16 ha.LSU ${ }^{-1}$, Eastern Mixed Karoo.

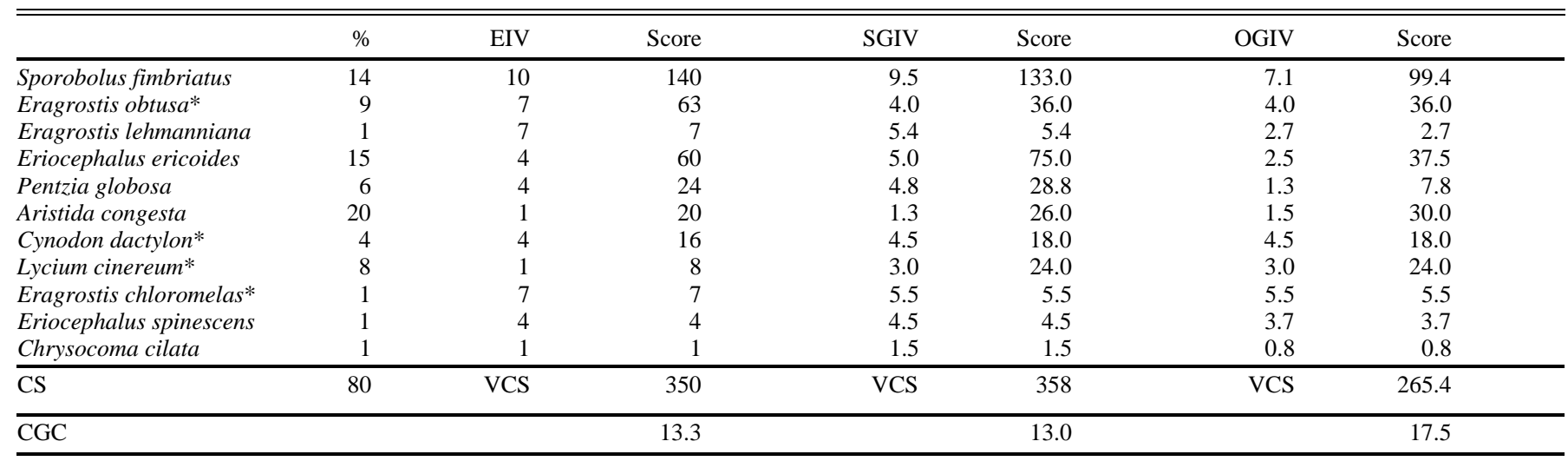


(Table 4. Continued)

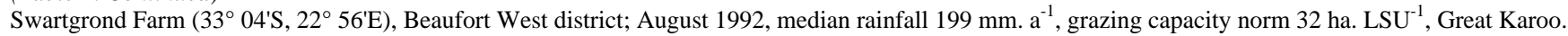

\begin{tabular}{|c|c|c|c|c|c|c|c|}
\hline & $\%$ & EIV & Score & SGIV & Score & OGIV & Score \\
\hline Aristida congesta & 2 & 1 & 2 & 1.3 & 2.6 & 1.5 & 3.0 \\
\hline Protasparagus suaveolens* & 1 & 1 & 1 & 1.0 & 1.0 & 1.0 & 1.0 \\
\hline Pentzia incana & 14 & 4 & 56 & 5.7 & 79.8 & 1.5 & 21.0 \\
\hline Eberlanzia ferox & 1 & 1 & 1 & 2.7 & 2.7 & 2.0 & 2.0 \\
\hline Hermannia desertorum & 5 & 7 & 35 & 5.9 & 29.5 & 1.2 & 6.0 \\
\hline Stipagrostis obtusa & 2 & 10 & 20 & 6.6 & 13.2 & 2.4 & 4.8 \\
\hline Eriocephalus ericoides & 1 & 4 & 4 & 5.0 & 5.0 & 2.5 & 2.5 \\
\hline Pteronia sordida* & 1 & 4 & 4 & 4.5 & 4.5 & 4.5 & 4.5 \\
\hline Eriocephalus spinescens & 1 & 4 & 4 & 4.5 & 4.5 & 3.7 & 3.7 \\
\hline Enneapogon desvauxii* & 1 & 1 & 1 & 1.0 & 1.0 & 1.0 & 1.0 \\
\hline Stipagrostis ciliata & 2 & 10 & 20 & 7.2 & 14.4 & 5.8 & 11.6 \\
\hline Felicia filifolia & 1 & 7 & 7 & 5.9 & 5.9 & 2.6 & 2.6 \\
\hline Zygophyllum microphyllum & 1 & 4 & 4 & 4.0 & 4.0 & 3.8 & 3.8 \\
\hline
\end{tabular}

Abrahamskraal Farm ( $\left.31^{\circ} 46^{\prime} \mathrm{S}, 22^{\circ} 40^{\prime} \mathrm{E}\right)$, Victoria West district; February 1992, median rainfall $227 \mathrm{~mm} \cdot \mathrm{a}^{-1}$ grazing capacity norm 26 ha.LSU ${ }^{-1}$,Central Upper Karoo.

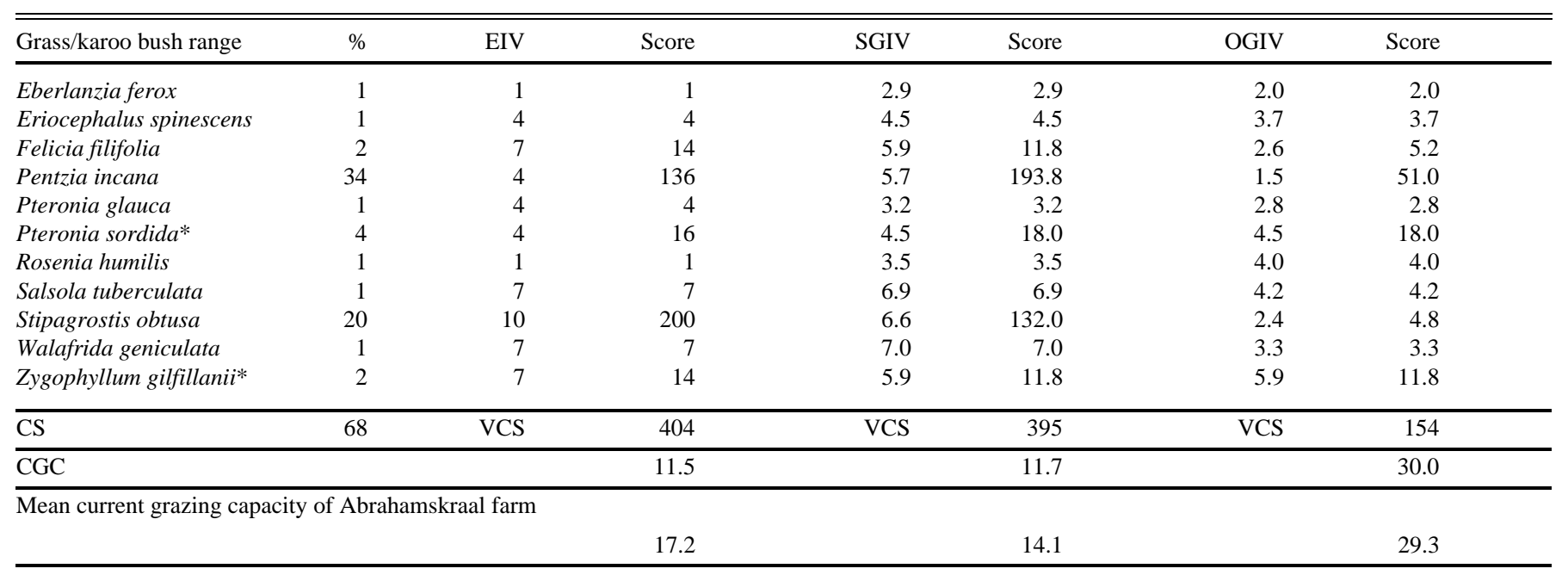

\section{Conclusions}

The objectively estimated grazing index values verifies the relative position of the species in the series and they can be compared to the subjective grazing index values developed earlier at the Grootfontein Agricultural Development Institute (Du Toit et al. 1995).

It is possible to objectively estimate grazing index values for plant species of the arid areas by means of a suitable model. In the estimates used in the model, certain plant variables such as the canopy spread cover, the available forage on the plant and the chemical content of the available forage at that instant, play prominent roles.

The objective grazing index values have been successfully used in the computation of range condition scores and in the calculation of current grazing capacities from these range condition scores (Table 4). These current grazing capacities have been estimated for widely differing areas. It is clear that they closely approximate the long-term grazing capacity norms prescribed for these areas by the South African Department of Agriculture.

\section{Literature Cited}

Acocks, J.P.H. 1988. Veld Types of South Africa. Memoirs of the Botanical Survey of South Africa 57:1-146. Gov. Printer, Pretoria.

Arnold, T.H. and B.C. De Wet. 1993. Plants of Southern Africa: Names and Distribution. Memoirs of the Bot. Survey of So. Afr. 62:1825. Nat. Bot. Institute, Pretoria
Association of Official Agricultural Chemists (AOAC) 1964. Official methods of analysis of the association of official agricultural chemists, 9th Ed, edited by W. Horwitz. Washington, DC.

Bartholomew, P.E. 1985. Beef production from kikuyu and Italian ryegrass. Ph.D. Thesis. Univ. of Natal, Pietermaritzburg.

Botha, P. 1981. The influence of species selection by sheep, cattle and goats on the floristic composition of mixed Karoorange. (In Afrikaans: Die invloed van spesieseleksie deur skape, beeste en bokke op die floristiese samestelling van gemengde Karooveld.) D.Sc. thesis. P.U. for C.H.E., Potchefstroom.

Botha, P. and C.B. Nash. 1990. Mean phytomass and chemical composition of a number of plant species in the Karoo Midlands. Tech. Comm. no. 228. Gov. Printer, Pretoria.

Botha, P., H.R. Becker, and I.J. Van Der Merwe. 1990a. Mean phytomass and chemical composition of a number of plant species in the Great Karoo. Tech. Comm. no. 226. Gov. Printer, Pretoria. 
Botha, P., C.H. Erasmus, and S.C. Theron. 1990b. Mean phytomass and chemical composition of a number of plant species in the Nortwestern Karoo. Tech. Comm. no. 227. Gov. Printer, Pretoria.

Botha, P., W.H. Van Staden, and J.D. Blom. 1990c. Mean phytomass and chemical composition of a number of plant species in the Northeastern Karoo. Tech. Comm. no. 229. Gov. Printer, Pretoria.

Botha, W. Van D, P.C.V. Du Toit. C.D. Blom. H.R. Becker. D.J. Olivier. E.M. Meyer, and G.Z.J. Barnard. 1993. A technique for estimating the grazing index values of Karoo plants. Karoo Agr. 5(2):10-14.

Bredon, R.M. and H.J. Meaker. Undated. How to calculate TDN and DCP of feeds. Leaflet no. 54. Cedara Agricultural Development Institute, Pietermaritzburg.

Brown, R.T. and J.T. Curtis. 1952. The upland conifer-hardwood forests of northern Wisconsin. Ecol. Mono. 22:217-234.

Cook, C.W., L.A. Stoddard, and L.E. Harris. 1952. Determining the digestibility and metabolizable energy of winter range plants by sheep. J. Anim. Sci. 11:578-590.

Curtis, J.T. and R.P. McIntosh. 1951. An upland forest continuum in the prairie-forest border region of Wisconsin. Ecol. 32:476-496.

Du Toit, P.C.V. 1993. Stocking rate vs defoliation of karoobushes. Karoo Agr. 5(1):17-21.

Du Toit, P.C.V. 1995. Grazing index method of range condition assessment and comparison of techniques. African J. Range For. Sci. 12(2):61-67.

Du Toit, P.C.V. 1996a. Karoobush defoliation in the Arid Karoo. J. Range Manage. 49:105-111.

Du Toit, P.C.V. 1996b. Development of a model to estimate grazing index values for Karoo plant species. Ph. D. Thesis. Univ. of Pretoria, Pretoria.

Du Toit, P.C.V. and W. Van D. Botha. 1993. Grazing Index Values of Karoo Plants. Paper read at the Arid Zone Ecology Forum held at Middelburg, 28 to 30 September 1993. Abst. Proc. Arid Zone Ecol. Forum 1993:30-31.

Du Toit, P.J,, J.G. Louw, and A.I. Malan. 1940. The feeding value of the natural grazings of the Union of South Africa (In Afrikaans: Die voed ingswaarde van die natuurlike weivelde van die Unie van SuidAfrika.) Farming in So. Africa 15:229-232.

Du Toit, P.C.V., W. Van D. Botha. C.D. Blom. H.R. Becker. D.J. Olivier. E.M. Meyer, and G.Z.J. Barnard. 1995. Estimating grazing index values for Karoo plants. Tech. Comm. no. 239. Gov. Printer, Pretoria.

Edwards, P.J. 1981. Grazing management. In: Tainton, N.M. (ed.) Veld and Pasture Management in South Africa, pp 315-336. Shuter and Shooter, Pietermaritzburg.
Foran, B.D., N.M. Tainton, and P. De V. Booysen. 1978. The development of a method for assessing veld condition in three grassveld types in Natal. Proc. Grass. Soc. So. Africa 13:27-33.

Glover, J., D.W. Duthie, and H.W. Dougall, 1960. The total digestible nutrients and gross digestible energy of ruminant feeds. J. of Agr. Sci.. 55:403-408.

Goebel, C.J., L. Debano, and R.D. Lloyd. 1958. A new method of determining cover and production on desert shrub vegetation. J. Range Manage. 11:244-246.

Hardy, M.B. and C.R. Hurt. 1989. An evaluation of range assessment techniques in Highland Sourveld. J. Grass. Soc. So. Africa 6:51-58.

Homer, D.C. and F.B. Parker. 1961. Methods of analysis for soil, plants and water. Univ. of California, Berkeley, Calif.

Hurt, C.R. and O.J.H. Bosch. 1991. A comparison of some range condition assessment techniques used in southern African grasslands. J. Grass. Soc. So. Africa 8:131-137.

Kemp, A. and M.L. T'Hart. 1957. Grass tetany in grazing milking cows. Netherlands J. Agr.. Sci. 5:4-17.

Kidambi, S.P., A.G. Matches, and T.C. Griggs. 1989. Variability for $\mathrm{Ca}, \mathrm{Mg}, \mathrm{K}, \mathrm{Cu}$, $\mathrm{Zn}$ and $\mathrm{K} \div(\mathrm{Ca}+\mathrm{Mg})$ ratio among 3 wheatgrasses and sainfoin on the southern high plains. J. Range Manage. 42:316-322.

Louw, G.N. 1969. The nutritive value of natural grazings in South Africa. Proc. So. African Soc. Anim. Prod. 8:57-61.

Louw, G.N., C.W.P. Steenkamp, and E.L. Steenkamp. 1968a. Chemical composition of the most important plant species in the Noorsveld. Tech. Comm. no. 77. Gov. Printer, Pretoria.

Louw, G.N., C.W.P. Steenkamp, and E.L. Steenkamp. 1968b. Chemical composition of the most important plant species in the Western Mountain Karoo in the Fraserburg District. Tech. Comm. no. 78. Gov. Printer, Pretoria.

Louw, G.N., C.W.P. Steenkamp, and E.L. Steenkamp. 1968c. Chemical composition of the most important plant species in the Arid, Semi-Arid, False Succulent and Central Upper Karoo. Tech. Comm. no. 79. Gov. Printer, Pretoria.

McDonald, P., R.A. Edwards, and J.F.D. Greenhalgh. 1973. Animal nutrition. Oliver and Boyd, Edinburgh.

Maynard, A.L. and J.K. Loosli. 1962. Animal nutrition. McGraw-Hill, New York.

Mentis, M.T., R.F.H. Collinson, and M.G. Wright. 1980. The precision of assessing components of the condition of moist tall grassveld. Proc. Grass. Soc. So. Africa 15:43-46.

Mueller-Dombois, D. and H. Ellenberg. 1974. Aims and methods of vegetation ecology. John Wiley and Sons, New York.

Payne, G.F. 1974. Cover-weight relationships. J. Range Manage. 27:403-404.
Roux, P.W. 1963. The descending-point method of vegetation survey. A point sampling method for the measurement of semiopen grasslands and Karoo vegetation in South Africa. So. African J. Agr.. Sci. 6:273-288.

Sneva, F.A. and D.N. Hyder. 1962. Estimating herbage production on semiarid ranges in the intermountain region. J. Range Manage. 15:88-93.

Statistical Graphics Corporation 1991. Statgraphics. STSC Inc, Maryland.

Steenkamp, C.W.P. and F.C. Hayward. 1979. Chemical composition of the most important plant species in the south-central sector of the Great Escarpment. Tech. Comm. no. 149. Gov. Printer, Pretoria.

Swift, R.W. 1957. The caloric value of TDN. J. Anim. Sci. 16:753-755.

Tainton, N.M. 1981. The ecology of the main grazing lands of South Africa. In: N.M. Tainton (ed.), Range and Pasture Management in South Africa, pp 25-56. Shuter and Shooter, Pietermaritzburg.

Tainton, N.M., P.J. Edwards, and M.T. Mentis. 1980. A revised method for assessing veld condition. Proc. Grass. Soc. So. Africa 15:37-42.

Uresk, D.W. 1990. Using multivariate techniques to quantitatively estimate ecological stages in a mixed grass prairie. J. Range Manage. 43:282-285.

Van Der Merwe, F.J. 1985. Animal Nutrition (In Afrikaans: Dierevoeding.) Kosmo publishing house, Stellenbosch, pp. 1-260.

Van Hoven, W. and H. Ebedes. 1988. Nutrition, carrying capacity and care of young animals (In Afrikaans: Voeding, drakrag en versorging van jong diere.) In: Bothma, J. Du P. (ed.) Wildplaasbestuur, Van Schaiks, Pretoria, pp 1-616.

Van Soest, P.J. 1963. The use of detergents in the analysis of fibrous feeds: II A rapid method for the determination of fibre and lignin. J. Assoc. Agr. Chem. 46:829.

Vlok, J.J.A.L. 1963. The nutritional value of the natural forages in the border region between the winter and summer rainfall regions in the district of Calvinia. (In Afrikaans: Die voedingswaarde van die natuurlike weidingsgewasse in die grensgebied tussen die winter-en somerreënstreke in die distrik Calvinia.) M.Sci. Agr. Diss. Univ. of Stellenbosch, Stellenbosch.

Vorster, M. 1982. The development of the Ecological Index Method for assessing veld condition in the Karoo. Proc. Grass. Soc. So. Africa 17:84-89.

Wilkes, M. 1989. Operational research : Analysis and applications. McGraw-Hill Book Co., London.

Woods, F.W. 1959. Nutritional aspects of Wiregrass from West Florida Sandhills. J. Range Manage. 12:141. 